\title{
Discipline Unbound: Patuxent, Treatment and the Colonization of Law
}

Convict Joins Own Blood Stream to That of Girl Dying of Cancer so ran the front-page headline in the Saturday edition of the New York Times of June 4, 1949. Over the course of the next few days, the paper’s readers were introduced to Louis Boy, a Sing Sing prisoner who had responded to a call from the Commissioner of Correction for "a prisoner volunteer willing to undergo a hazardous experiment involving leukemia”. Laying side by side, their circulatory systems linked by rubber tubing, Boy and the dying 8 year-old exchanged 9,000 cubic centimeters of blood (18 quarts) over the next four days. Would Boy’s circulatory system successfully filter out Marcia Slater's leukemia? Could the transfusion infect the 49 year-old convict with the little girl's disease? The paper wove a compelling narrative of redemption and heroism unfolding in a hospital ward a stone's throw from Sing Sing’s austere outer walls. In light of his repeated participation in "various dangerous medical tests and experiments,” the Governor pardoned Boy’s life sentence for murder later that year; Slater died shortly after the transfusion. ${ }^{1}$

The life and death drama of the case overshadowed the procedure's futility. As an editorial by the Chief of Cancer Research at the Veteran's Administration Hospital explained, the experiment would only confirm what was already well known. Leukemia was not transmissible through blood transfusion and the operation would, at best, provide only a temporary improvement in Slater's condition but could never cure her. Further, given the unknown risks involved in injecting a healthy body with such a massive quantity of leukemic blood (a medical first) and that the same result could have been achieved using blood from a blood bank, the experiment posed a dangerous affront to humanity and scientific ethics. ${ }^{2}$

Boy’s case was hardly unique. Newspaper chronicles of medical experimentation and research breakthroughs throughout the 1940s, 50s and 60s routinely praised the selflessness of convict 
test subjects and their wide suitability for first stage clinical testing. ${ }^{3}$ These heroic narratives drew upon themes of rehabilitation and penitence in circulation since the late $18^{\text {th }}$ century, injecting novelty into the tired trope of reform through hard labor and confirming the notion that prisons could still stage individual acts of redemption. At the same time, such accounts provided ideological cover for a broad array of experimental projects that, even as they disavowed penal exclusion and earlier models of convict ‘less-eligibility’, actively furthered new terrains of dehumanization and legal disfigurement. ${ }^{4}$ In this sense, the prison-as-laboratory formed an important backdrop against which the formulation of much more ambitious regimes were framed. If cell-cultures, skin grafts and organ transplants on prisoner bodies could further medical knowledge, could not the experimental method unlock models for diagnosis and intervention on offenders themselves? Penal reformers concerned with the justice system's overreliance on criminal responsibility and arbitrary punishment embraced the idea. ${ }^{5}$ State legislators under the sway of new behavioural constructions of criminality, endorsed new laws designed to isolate "pseudo-criminal” populations and to house them in purpose-built facilities. ${ }^{6}$

Patuxent institution (Jessop, Maryland) was perhaps the most emblematic representation of this mid-century encounter between clinical science and criminal justice. For more than twenty years (1955-1977) it comprised a unique experiment in both discipline and law. Legally, the institution was not a mental institution, a prison or a hospital but "exercised some of the functions of all three" (Blizzard v. State, 1958). According to Maryland law, it was to be exclusively directed by social science "experts" and its head administrator was required to be a psychiatrist. Its charges, committed under the "defective delinquency" act, were convicted criminals that straddled an ambiguous position between legal sanity and insanity, criminality and pathology. At the same time, the constitutionality of defective delinquency and the legitimacy of Patuxent were incessantly challenged throughout the institution's history. The extensive body of litigation that emerged, which forms the empirical material for this paper, represents an on-going engagement of law with psychiatric science and provides unique insight into how disciplinary power is enabled, understood, and resisted within legal discourse and interpretation. 
Michel Foucault famously theorized the rise of disciplinary power, its role in constituting areas of knowledge and expertise, as well as its progressive articulation within institutions through tactics of normalization and techniques of self-regimentation. A central theme in Foucault's treatment of the disciplinary norm's ascendance involves understanding what role law plays alongside these new modalities of power. ${ }^{7}$ Does the relevance and applicability of law, so often characterized by Foucault as an instrument of sovereignty, recede in the face of the new disciplinary arrangements? Conversely, does law continue to figure as an important facet in the arrangement and legitimation of discipline and, if so, what is its specific role?

In what follows, I engage these questions through the case study of Patuxent Institution. I argue that Article $31 \mathrm{~B}$ (as the defective delinquency statute was known) set up a zone of expert prerogative and discretion actively maintained and legitimated through judicial opinion and interpretation. Yet, paradoxically, law also functioned as a conduit for resistance and contestation pitting the epistemological premises of discipline against the functions of legal jurisprudence and the foundations of criminal law. I contend that this dual character of law's engagement with discipline (i.e., at once open to expert “colonization” and site of structural incompatibility and resistance) illustrates the intractability of the relationship between discipline and law. That is, law both constitutes disciplinary space (and within this normative envelope, discipline can be “unbound”) and remains in a state of tension with the forms of power that develop within it (which by their very premises seek to exceed the limits law would place upon them). Thus, paradoxically, law remains an effective site of resistance to disciplinary power and a discursive space where it can be interrogated and contested.

\section{Civil Strictures and the Ends of Criminal Law}

Maryland's defective delinquency statute can be contrasted with traditional modes of representing the state's power to punish. Nineteenth and early twentieth century criminal law framed penal subjectivity in almost deontological terms whereby prisoners were deemed "civilly dead" or 
"slaves of the state" as a result of their own wilful intransigence. ${ }^{8}$ Article 31B embodies an explicit critique of this "sovereign" model of punishment and its prioritization of deserts and deterrence over diagnosis, treatment and rehabilitation. Yet it also seeks to go significantly beyond the traditional categories, procedures and ends of criminal law (e.g., guilt and proportionality) by framing the criminal act as the product of pathology rather than rational choice or socio-economic factors:

[T]he purpose of the proposed law is to expand, as a practical matter but not by actual definition, the concept of the area of insanity... Like the lunatic the incurable criminal defective would be confined for life, not because of guilt, but to protect the defective himself and society. ${ }^{9}$

The rationale behind the new statute was outlined in a 1952 monograph Psychiatry and the Law, co-authored by Manfred S. Guttmacher (a practicing psychiatrist, chairman of Patuxent’s Advisory Board and Chief Medical Officer of the Supreme Bench of Baltimore City). In a chapter entitled “The New Direction in Law”, Guttmacher and Henri Weihofen (a law professor) argued that a criminal's danger to society rather than moral culpability or blameworthiness, should form the central criterion upon which criminal justice rests. According to the authors, criminal law was tainted by “metaphysical supposition” and quaint traditionalism—a tendency exemplified by the search for proportionality between crime and punishment or by the concept of mens rea which remained entangled with archaic notions of sin and retribution. ${ }^{10}$ These obscured the modern, diagnostic capacity of psychiatric science and the reorganization of justice it warranted. Why should the power to determine an individual's state of mind, or the capacity to treat a recidivist for that matter, remain vested in the hands of a lay jury or judge unqualified in reading the cipher of the human mind?

Guttmacher and Weihofen's proposals involved nothing short of a complete overhaul of the criminal trial and the ideology of state punishment that underpinned it. Guilt-finding processes would be differentiated from sentencing and a new division of labor furthered between the juridical and social science. The former should be closely confined to matters of fact: did the defendant commit the crime? Questions of incapacitation and treatment, on the other hand, should be placed squarely in the domain of the latter: 
Fixing the sentence should therefore either be taken from the judge entirely and vested in a tribunal composed of experts qualified to evaluate psychiatric, psychological, and sociological data, or, if the judge be allowed to continue to pass sentence, the sentence should be a wholly indeterminate one, under which the person could be held as long as necessary, whether that be for a few days or for the rest of his life. ${ }^{11}$

Psychiatry and the Law argues that in light of the advances of clinical science the very notion of punishment (and perhaps even criminal law itself) becomes obsolete. Indeed the authors intimate that the role of judge, if not for its important socio-psychological functions, could be done away with entirely: “[t]he symbol of the wise and just father punishing wrong-doers, probably adds to the stability of society and to the average individual's feeling of security". ${ }^{12}$

The model of criminal justice proposed by Psychiatry and the Law was given institutional form by Patuxent Institution and article 31B. Patuxent was a purpose-built facility designed to diagnose, incapacitate and treat “defective delinquents," a category of convicted criminals defined as: ... [A]n individual who, by the demonstration of persistent aggravated antisocial or criminal behavior, evidences a propensity toward criminal activity, and who is found to have either such intellectual deficiency or emotional unbalance, or both, as to clearly demonstrate an actual danger to society... (Md. Ann. Code art. 31B)

Under the act, an individual sentenced in a Maryland criminal court in certain eligible crime categories or who had been convicted multiple times could, on the recommendation of the defendant, his lawyer, the judge, the prosecutor or the Chairman of the Board of Corrections, be ordered to undergo examination at the institution. ${ }^{13}$ If the institution determined that the prisoner was indeed "defective,” a hearing before the same judge and in the same criminal court that convicted him would follow.

Commitment hearings bore many of the markers of criminal procedure. The accused entered a plea of "guilty" or "not guilty" and could choose to have a jury empanelled to decide the case. He retained the right to counsel, to inspect the prosecution's evidence, to call witnesses and crossexamine them, as well as being entitled to examination by an independent psychiatrist. Despite these 
safeguards, the defective delinquency act was legislatively drawn and judicially interpreted as regulatory. That is, because commitment hearings were ultimately civil (and not criminal) procedures the question of whether the full scope of criminal protections applied to defendants remained ambiguous and contentious—-particularly given that Patuxent commitments involved indefinite confinement for a period that routinely exceeded the length of a defendant's original criminal sentence.

In keeping with their civil construction, and echoing Guttmacher and Weihofen’s recommendations, commitments invoked criminal procedure but systematically displaced its substantive elements. Juries, for example, were restricted to matters of fact only and not law and fact as occurs in criminal trials (Purks v. Director, 1961) and although defendants retained the capacity to cross-examine witnesses and consult state evidence, the broad nature of the inquiry limited their exercise. The prosecution typically presented its case with just one witness (Patuxent's director, a psychiatrist) and one written report.

James Palmer's case illustrates just how comprehensive such reports could be. The document produced at Palmer's defective delinquency hearing stretched back ten years. At that time he was examined by Dr. Esther Richards who recalled him as being "very psychopathic”, the report also featured the opinion of a Dr. Samuel Novay who saw him in 1945, 1949 and 1950 (Palmer v. State, 1957). Novay determined that because Palmer could not control his behaviour and was not susceptible to psychiatric treatment, he should be confined in an institutional setting for the maximum period allowed by law. The document also contained the report of Dr. Edgar Smith (a psychiatrist and Patuxent's Associate Director) and two further reports from the institute's staff by Robert Traylor (a physician) and Sigmund H. Manne (a criminal psychologist). Of all these experts, the sole witness produced by the state and whose testimony was open to examination was Dr. Edgar Smith.

As a dossier of expert opinion and interpretation, the report aimed at a full documentary, biographical and clinical reconstruction of the individual. It generated the powerful knowledge asymmetries necessary for perpetuating Patuxent's epistemological truths and was typically a composition of: staff observations and impressions, admissions of previous criminal or anti-social 
conduct, and the results of the institute's formal examination (by a psychiatrist, psychologist and doctor). It might also include discussions with family and friends, as well as any other records about the individual that might have been institutionally generated (e.g., military history, juvenile file, school records etc.). Even in those cases where the institution failed to produce a report because of an individual's resistance to examination, Patuxent's deep biographical probe systematically attacked the integrity of a suspect's self-narrative:

One staff member after interviewing McNeil reported: "He adamantly and vehemently denies, despite the police reports, that he was involved in the offense"; "Further questioning revealed that he had stolen some shoes but he insisted that he did not know that they were stolen ..."; "but in the tenth grade he was caught taking some milk and cookies from the cafeteria"; "He consistently denies his guilt in all these offenses"; "He insisted that he was not present at the purse snatching"; "He was adamant in insisting on this version of the offense despite the police report which was in the brief and which I had available and discussed with him"; "He continued his denial into a consideration of a juvenile offense ..."; "He denies the use of all drugs and narcotics". ${ }^{14}$

The above passage, an excerpt from McNeil's petition, underscores the inquisitorial character of the examination process and its wide, unbounded scope. These characteristics, when combined with the dramatic asymmetry of expert knowledge marshalled in support, gave the institution's commitment reports an almost unassailable quality. Purks v. State (1961), for example, directly challenged the admissibility of Patuxent reports and their potential qualification as hearsay. Although the court agreed that Article 31B did not explicitly mention Patuxent reports as admissible evidence (and hence they were not formally exempted from the hearsay rule) and that “...it is true, as the appellant asserts, that the admitted reports were based in part on hearsay evidence,” the court denied the appeal, emphasized the integrity of the examination process and the necessary division of labor at the core of such hearings. 
[E]xpert findings and conclusions [of the three examiners] are to be accorded very serious consideration, particularly in a case such as this one, when the trial court almost necessarily must rely to a considerable degree on the opinions of expert witnesses. ${ }^{15}$

Both the role of the jury and the evidentiary status of Patuxent reports engendered significant definitional ambiguity, not just with respect to the proper procedural schema commitment hearings fell under but also with respect to the stability of defective delinquency as an objective classificatory category. This ambiguity was also furthered by the burden of proof the state was required to meet in delinquency hearings. ${ }^{16}$ Despite the fact that its targets were criminals, that hearings were initiated as a result of a criminal conviction and that they authorized open-ended and indeterminate incarceration, the prosecution was required to meet its burden of proof by a "preponderance of the evidence" rather than the more onerous "beyond a reasonable doubt" required in criminal trials. In other words, the elements of criminal procedure and review the statute adopted were not sufficiently binding to affect its civil character.

This interpretive position was consistently affirmed despite a steady stream of patientinitiated arbitration. In Director v. Daniels (1965), for example, the Court of Appeals considered the constitutionality of Article 31B and found the act met all six criteria identified by the Supreme Court for civil status. ${ }^{17}$ Beyond settling the constitutional question, the case helped reify the categorical indeterminacy at the core of the statute. Judge Hammond, writing the Court's opinion, argued that although the act did not further the traditional ends of criminal law (i.e., punishment, retribution and deterrence) its central rationale flowed directly from the state's police powers; the statute fused government's mandate to protect society with the humanitarian drive to treat, cure and rehabilitate those suffering from mental illness.

Director v. Daniels cast Patuxent as a novel and increasingly central element in the exercise of the state's police powers. Some years later, Judge Haynsworth’s opinion in Tippett v. State (1971) went significantly further. Six inmates challenged the constitutionality of Article 31B on the basis that Patuxent was de facto a penal institution and that commitment hearings amounted to criminal prosecutions. The plaintiffs contended that both offended due process on various counts. ${ }^{18}$ 
Haynsworth writing the opinion for the US Court of Appeals emphasized the civil nature of the proceedings and noted that a finding of defective delinquency rested on the mental and emotional condition of the person—not on any particular criminal act. More importantly, his conclusion situated the Maryland experiment within the wider context of progressivism and social transformation. As Chief Justice Burger of the Supreme Court had argued, a reappraisal of America's punitive philosophy was long overdue and Patuxent furnished a credible trajectory for reform:

[T]he clear promise it has demonstrated would be withdrawn should it be held...that the diagnostic and treatment processes should be converted into an adversary process in which the patient is entitled to all the constitutional protections available to a defendant in a criminal proceeding. It is difficult to imagine anything more stultifying to a psychiatrist, as dependent as he is upon the cooperation of his patient, than the presence of a lawyer objecting to the psychiatrist's questions and advising his client not to answer this question and that. The injection of broad legal restraints into the diagnostic and treatment procedures that would deny Patuxent's substantial prospect for improvement over our earlier practices might well restrain most other experimentation looking toward conversion of our correctional institutions into effective rehabilitative agencies. ${ }^{19}$

The above lays bare the legal and conceptual foundations of the Patuxent experiment and the synthesis of social science, medical knowledge and jurisprudence that constructed and actively maintained this space. Discipline was "unbound" by these legal opinions and discourses. One finds judges explaining and interpreting the status of the institution as outside of criminal guarantees and effectively surrendering sentencing to expert psychiatric opinion. Throughout this period, legal actors are seemingly the architects of their own eventual obsolescence by legitimating a mode of deploying power that, if followed to its logical conclusion, would effectively displace their own prerogative to judge.

A distinctive constellation of procedural and post-conviction remedies ensured that Patuxent's legal construction remained actively and intimately linked to its disciplinary structure through the battery of petitions and actions inmates pursued in the state's courts. ${ }^{20}$ In the next section, I draw upon 
Michel Foucault’s discussion of law's disciplinary colonization to examine this relationship up close. ${ }^{21}$ Patuxent seemingly confirms the observation that post-sovereign law would take on ever expanding regulatory functions and become increasingly penetrated by normative orientations. Yet in reading through the myriad of legal opinions that surround the institution, it remains striking that the primary architects of this experiment are legal actors (judges) working through established conventions actively seeking to shape a form of law with purely normative aims and horizons. That is, not only does the impetus and supporting architecture for defective delinquency come from deep within the halls of juridical-discursive power, but it is also a project that consciously seeks to replace or reinterpret its sovereign referent. ${ }^{22}$ This situation also poses new questions concerning the viability of resistance to the sort of "judridico-disciplinary complex" Patuxent represents. Under what conditions can law provide an effective instrument of resistance to disciplinary power if it is law itself that underpins and guarantees it?

\section{Framing Disciplinary Law}

The relationship between law and norm emerges in Michel Foucault's account of state formation in the Middle Ages and the rise of democratic constitutionalism in the $17^{\text {th }}$ and $18^{\text {th }}$ centuries. ${ }^{23}$ A quotation from the History of Sexuality is instructive:

The great institutions of power that developed in the Middle Ages—monarchy, the state with its apparatus—rose up on the basis of a multiplicity of prior powers...dense, entangled, conflicting powers, powers tied to the direct or indirect dominion over the land, to the possession of arms, to serfdom, to bonds of suzerainty and vassalage...Faced with a myriad of clashing forces, these great forms of power functioned as a principle of right that transcended all the heterogeneous claims, manifesting the triple distinction of forming a unitary regime, of identifying its will with the law, and of acting through mechanisms of interdiction and sanction. 
The sovereign establishes “...peace as the prohibition of feudal or private wars, and justice as a way of suspending the private settling of lawsuits.” ${ }^{24}$ In other words, sovereignty initially takes a juridical and negative form by presenting itself as an arbiter or referee; law codes this power and provides the rules under which it is represented and arranged (especially the relationship between sovereign and subject). However by the $17^{\text {th }}$ and $18^{\text {th }}$ centuries, this form of law beings to function as a component of regulatory apparatuses oriented in the direction of a norm rather than merely as an expression or extension of the sovereign's will. ${ }^{25}$ It is here that Foucault traces the gradual colonization of early modern law by a new form of power and principle for its manifestation.

[I]f it is true that the juridical system was useful for representing, albeit in a nonexhaustive way, a power that was centered primarily around deduction (prélèvement) and death, it is utterly incongruous with the new methods of power whose operation is not ensured by right but by technique, not by law but by normalization, not by punishment but by control, methods that are employed on all levels and in forms that go beyond the state and its apparatus. ${ }^{26}$ The catalyst for this legal transformation is linked to the wider diffusion of disciplinary techniques and tactics, beyond the prototypical institutions that incubated them and throughout the social body. Foucault notes that this period represents a "technological takeoff" in which disciplinary expansion reaches a critical point and engenders popular resistance. Seen in this light, as much as the rights-based claims of the French and American Revolutions (with their calls for life, liberty, equality and self-determination) represented critiques of sovereign power framed in the language of law (i.e., rights) and reified the existing structure and currency of power (e.g., they did not challenge the notion of the rule of law) they were also political movements informed by, responsive of, and arranged against the increasing ascendance of disciplinary technologies. In other words, though the revolutionaries deployed the language of rights and attacked Monarchical prerogatives they also unwittingly inscribed an enduring relationship between sovereign and disciplinary power at the foundations of modern democratic law.

The above foundational moment paves the way for law's penetration by the disciplinary norm but it is also important to bear in mind that this is not a one-way street. Discipline remains open to 
legal interrogation and law continues to serve as a conduit for resistance. Indeed it is clear that Foucault thought this drama continued to be played out in an almost perpetual back and forth: [W]hen we want to make some objection against disciplines and all the knowledge-effects and power-effects that are bound up with them, what do we do in concrete terms? What do we do in real life?...We obviously invoke right, the famous old formal, bourgeois right. And it is in reality the right of sovereignty. And I think that at this point we are in a sort of bottleneck, that we cannot go on working like this forever; having recourse to sovereignty against discipline will not enable us to limit the effects of disciplinary power. ${ }^{27}$

It would seem that some elements of sovereignty continue to play an important role in the dialectics of resistance. There are at least two important reasons why this might be the case. Firstly, disciplinary systems require legal framing not just to lend them legitimation but to actually constitute the rules, authority structures and capacities that will inhabit them. ${ }^{28}$ Secondly, the rise of democratic constitutionalism did not simply open the legal complex to the slow penetration of disciplinary norms but it also dramatically resituated the terms of power within the sovereign compact. Thus, in step with the rise of individual rights, the binary logic of interdiction and prohibition came to be applicable to the sovereign himself (or the state). For example, many of the fundamental rights contained in the US Constitution (e.g., the Bill of Rights) are framed precisely in terms of prohibitions against earlier sovereign prerogatives. It is this arrangement—a legal undercarriage to the disciplinary machine and a society of legal subjects capable of making justiciable claims of authority — that gives individual tactics of resistance a degree of traction.

Yet which tactics of resistance are available for those that would use law against disciplinary strategies and how might one assess their outcomes? The answer is hardly straightforward, partially because different disciplinary systems and institutions are incorporated in (and open to interrogation through) legal frameworks and mechanisms in varying degrees. But just as importantly, one’s position within a system and one’s capacity to tactically mobilize law to one’s ends (however limited its potential impact may be) is also variable. Thus, for example, those whose lives are “...surrounded and 
entrapped by legal rules as well as by officials and institutions which claim authority to say what the law is and what the rules mean...” develop a different insight about and tactical relationship with law as compared to those for whom contact is episodic or fleeting. ${ }^{29}$

An instrumental and intimate knowledge of law, developed through ongoing interactions and transactions with legal officials and institutions (as in Austin Sarat's above example of the welfare poor) can engender windows of opportunity, the possibility for strategically maneuvering between its different domains and for carving out spaces of resistance. ${ }^{30}$ In a similar vein, Patuxent’s unique position between punishment and treatment, its ongoing interrogation through review procedures and prisoner litigation, allowed its inmates to exploit the gaps and elisions between the epistemological premises of juridical and disciplinary domains. Yet such a situation was also facilitated by the institution's indeterminate structure; the unresolved synthesis of criminal law and disciplinary norms that formed the bedrock of its treatment regime routinely generated its own pockets of instability. Understanding why this might be the case requires a brief recapitulation of how sovereign and disciplinary logics unfold, as well as the role of abnormality in their reproduction.

Foucault frequently frames law as being caught up in the logic of sovereignty—a reference to the problem that origins and foundations pose for sovereign power.

That the relationship of sovereignty is thus founded on precedence and reactualized by a number of more or less ritual actions stems from the fact that the relationship is, in a sense, intangible, that it is given once and for all but, at the same time, is fragile and always liable to disuse or breakdown. ${ }^{31}$

Sovereignty requires a liturgy or ceremonial that can reactivate it and connect the present instantiation of power with its original foundations. ${ }^{32}$ Modern constitutional democracies also exhibit elements of this self-referential logic; within the field of jurisprudence, law is seemingly in continual dialogue with its founding principles and documents, incorporating new social forms through a reinterpretation of constitution or common law. Thus a central facet of legal interpretation involves the ongoing process of confirming which boundaries set by law will remain valid and which need reorientation. And throughout this enterprise, legal decisions, categories and statuses, impose a binary logic upon 
social reality (e.g., a contract is either valid or invalid, a defendant is either guilty or not guilty, a particular right is either applicable or it is not).

Sovereign power is oriented towards some original act, right or event but disciplinary power looks to the future. The referent of discipline is the fulfilment of its potential hegemony, the realization of the optimal state of affairs (at the level of people, movements and actions), the automation of supervision and the habituation of compliance. ${ }^{33}$

There is a genetic polarization, a temporal gradient in discipline, exactly the opposite of the reference to precedence that is necessarily involved in relationships of sovereignty. All discipline involves this kind of genetic course by which, from a point, which is not given as the inescapable situation, but as a zero point of the start of discipline, something must develop such that discipline will keep going by itself. ${ }^{34}$

In this context the norm represents the principle or common standard of judgment against which individuals can be measured, compared and evaluated; a norm frames a distribution of positions arranged in terms of their closeness or distance from it. And normality describes those positions that are, or have the potential to be at some future date, compatible and correspondent with the norm.

However, because disciplinary systems function according to principles of distribution, hierarchization and classification they are also very efficient at generating “residues”; they routinely render visible individuals that escape or fall outside a particular system's capacity to classify and normalize them. ${ }^{35}$ Abnormality is both limit category and catalyst for a disciplinary system's expansion and reproduction.

...Disciplinary power has this double property of being "anomizing,” that is to say discarding certain individuals, bringing anomie, the irreducible, to light, and of always being normalizing, that is to say, inventing ever new recovery systems, always re-establishing the rule. What characterizes disciplinary systems is the never-ending work of the norm in the anomie. $^{36}$

Thus the abnormal is present at the inception of a disciplinary system (as the core rationale for setting one up) but also helps frame its limits since new interventions, systems and institutions will need to be 
deployed to deal with any new accumulation of anomie that appears. But if as we have seen, discipline and law remain entangled, re-establishing the rule necessarily requires some normative and legal recalibration. And it is here that discipline's exposure to the claims and demands generated from within law become particularly relevant. The category of the abnormal brings the norm into interrogation by law; it brings the divergent horizons of discipline and law momentarily in sync and provides the backdrop for a restaging of the foundational drama. In these moments law can become a conduit for resistance, transforming a revolt against the norm into a platform for the law's reinvention and, at the same time, a new iteration of disciplinary power.

That the above potential remains largely theoretical throughout the routine operation of disciplinary institutions is partially due to the fact that disciplinary authority tends to replicate legal frameworks for adjudication and grievance through internal bodies and procedures. A degree of abnormality can also be collapsed within the margins of variance projected by any normative system. Yet, as I argue below, abnormality remains an unstable and potentially explosive element because it generates disciplinary and epistemic ambiguities that cannot be resolved internally. That is, because it involves a foreign element that escapes the system's own hegemonic self-understanding it can be an effective position from which to force alternative interpretations of discipline’s power effects.

\section{Resistance and the Abnormal}

Patuxent operated a "total treatment environment" oriented exclusively towards normative progression. Drawing upon Skinner's work on operant conditioning and reinforcement theory, the institution encouraged its prisoners to “...develop personal responsibility for one's behavior through the development of an internal set of controls”. ${ }^{37}$ Behaviorally, this meant the promotion of desirable conduct through the use of "positive reinforcers" or the threat of their withdrawal and curtailment. In this respect Patuxent echoed numerous behaviour modification programs available in therapeutic and clinical settings throughout the United States. Some of these programs constructed internal “economies” in which patients received “tokens” or points as rewards for desirable behaviour that 
could then be saved to "buy" desired items and activities. Others were organized according to a graded tier-system where coveted items, activities and privileges were contingent upon progression through different treatment levels. ${ }^{38}$

Patuxent’s disciplinary model consisted of four levels. Upon admission all "patients” spent a minimum of 30-60 days on the bottom tier in a solitary, nine by six foot cell. They were denied books, letters and visitation privileges and were allowed showers once a week. Eligibility for promotion to level 2 was contingent upon successful involvement in work and therapy programs, as well as acceptable conduct for at least 30 days. Promotion from level 2 to level 3 required similar levels of engagement with the program and favourable conduct for 90 days; eligibility for level 4 required six months of good conduct.

The "positive reinforcers” connected with progression between levels significantly impacted the contours of inmate life. For example, "lights out" on level 1 was at 10pm but level 4 prisoners could stay up as late as they wanted; tier 1 prisoners were denied visitation privileges but tier 4 prisoners had no restrictions on the number of visits per month and were encouraged to have Sunday afternoon picnics on the prison lawn with families and guests. Tier 4 patients could paint and decorate their cells, enjoyed a comfortable day-room with TV, magazines and a pool table as well as being free to move around their wing and the grounds relatively unencumbered. Indeed, the very visibility of tier 4 inmates and their privileges was designed to generate an aspirational culture: level 3 was organized so that its inmates could look into level 4 and glimpse its material improvements. ${ }^{39}$

Ideally the system’s incentive structure, its weekly group therapy sessions and vocational programs, as well as the possibility of release (one became eligible for parole only after having reached levels 3 and 4) would combine to provide strong motivation for behavioural and cognitive self-change. Yet, a powerful coercive apparatus was never far below the surface. The institution was surrounded by a 30-foot high chain-link fence, encased in a sheet of "climb-proof” plastic and topped with barbed wire. Guards with high-power rifles manned the guard towers and all the windows in the main two compound buildings were outfitted with steel bars. Inside the facility, grill gates and locked 
doors were as common as in most maximum security prisons and all tiers were closed off by steel doors. $^{40}$

Staff also made ample use of disciplinary segregation for inmates whose behaviour failed to comply with institutional rules or for those who failed to cooperate with the myriad of clinical assessments and therapy sessions that punctuated daily routine. Besides the four tiers of cells that graded, organized and integrated prisoner life, the institution had two rows of smaller cells it used for punishment (in institutional parlance "negative reinforcers”). Filthy, roach-infested and completely dark these cells housed prisoners undergoing “deprivation schedules” that sometimes stretched multiple months. Other punishments took a more traditional form: prisoner accounts described macing, hosing, food deprivation, beatings and various other brutalities. ${ }^{41}$

The most common source of prisoner frustration, and a potent tool of psychological violence in its own right, was the indeterminate sentence itself. "Patients” were on indeterminate sentences without "minimum or maximum length" and release required movement through the four tiers of responsibility until Patuxent’s Institutional Review Board (IRB) deemed one “cured” or no longer dangerous. The terms of progression were entirely subjective and one was more likely to be demoted or to languish at the top of the grade hierarchy than to progress towards parole. ${ }^{42}$ Furthermore, because confinement at Patuxent was treated as a civil commitment, one did not accrue credit against one’s original criminal sentence (Eggleston v. State, 1956); if the IRB so determined, the "patient" could be compelled to serve his full sentence or a portion of it in the state penitentiary after release from the institution. These broad discretionary powers when combined with the small army of experts on staff and the deference to scientific opinion embraced by the courts, meant that commitment to Patuxent could involve incarceration for life (or at the very least for significantly longer than one's original criminal sentence) in a regulatory zone largely hived off from the reliefs and remedies of constitutional and criminal law. ${ }^{43}$

Resistance under such total conditions was a long-term endeavour and heavily qualified. Prisoners filed a tremendous number of legal actions that challenged everything from the constitutionality of Patuxent and Article 31B to the minutiae of administration and institutional 
conditions. Many were dismissed or were used as opportunities to uphold the constitutionality of its regulatory construction (e.g., Sas v. State of Maryland, 1969). These suits and petitions failed because they sought to interrogate the institution's conditions, procedures and policies through the lens of criminal law under the assumption that Patuxent could be understood as a penal construct. It is only when inmate tactics shifted and resistance was directed at disciplinary power itself (as foothold to secure legal interrogation of the institution) that inmate suits began to have some measure of traction with legal authorities. Throughout the 1960s, the institution's inmates developed a series of tactics to resist disciplinary domination through peaceful non-engagement and by the early 1970s these individual trajectories of rebellion increasingly coalesced into more coordinated, group actions. Peaceful non-engagement was a particularly effective tactic because it engaged disciplinary power on its own terms by frustrating the logic of compliance which underpinned it and generating gaps in the system’s ideological coherence.

Normalized judgment generates compliance by locating individuals with reference to their proximity or distance from a desired norm of conduct; this perpetual ranking of individuals, ideally, generates a continuum within which the lowest rank exists only to disappear (i.e. move upwards in grade). ${ }^{44}$ Yet the "soft" model of compulsion requires active engagement from its targets; discipline's efficiency is proportional to its capacity to generate information that will help individualize its techniques and its capacity to be internalized by subjects so that it may function automatically. In this context, resisting all engagement with the psychiatric staff and refusing to be formally examined by the institution proved remarkably destabilizing. Peaceful non-engagement threatened the coherence of the system's aspirational economy but it also forced a categorical shift. If prisoners could not be diagnosed, how valid was Patuxent's jurisdictional claim to hold them indefinitely? If Patuxent failed to deliver therapy, vocational and educational interventions while they were confined, what made it different from a prison? And if Patuxent did, in at least these cases, cease to be an experimental treatment facility and become something akin to a penal institution; did the full force of criminal protections become applicable? 
Musgrove v. State (1966) was one of the first cases that tested the constitutionality of indefinite confinement at Patuxent without a determination of defective delinquency. Musgrove had been sentenced to state prison under an indeterminate sentence not to exceed 18 months for breaking into a storehouse. Two days later, the court ordered him transferred to Patuxent for examination as a “defective delinquent”. Throughout his stay at Patuxent, Musgrove politely complied with institutional rules but consistently refused to be examined by the psychiatric staff. As a result, the staff failed to provide the court with a report of its findings within the six-month window stipulated by statute. ${ }^{45}$ The prisoner then filed a petition of habeas corpus claiming that his sentence, allowing credit for good behaviour, had expired and that, since the state had been unable to file a report on his condition or to bring him to trial on "defective delinquency," he should be released. The Circuit Court for Montgomery County agreed with him, ordered Musgrove released and observed that given the possible consequences, cooperation with staff was not necessarily in the interest of examinees. ${ }^{46}$ Although the Court of Appeals found the lower court's habeas corpus decision non-appealable (and thus had to release Musgrove), it upheld the constitutionality of confining a noncompliant, suspected defective—even if his original sentence had expired—indefinitely.

The impact of the Musgrove ruling was soon put to the test in McNeil v. Director (1972). Convicted of two assaults in 1966, Edward McNeil was sentenced to a term of "not more than fiveyears” in state prison. Like Musgrove the court ordered him examined at Patuxent and, wary of selfincrimination because of a pending appeal, he similarly refused psychiatric testing, examinations and evaluations. McNeil eventually lost his appeal but that only seems to have strengthened his resolve. By the time his case reached the Supreme Court he had been confined at Patuxent for six years without examination and one year beyond the maximum on his sentence. ${ }^{47}$ Throughout this time he remained on the institution's receiving tier (under spartan conditions) and was denied access to therapy, vocational and educational training. Justice Douglas, in a sympathetic opinion, succinctly summarized the all-encompassing snare of disciplinary domination and the dense layers of legal indeterminacy that furthered it: 
First, the staff refuses to diagnose him, no matter how much information they may have, unless he talks. The result is that he never receives a hearing and remains at Patuxent indefinitely. Second, if there is no report on him, he remains on the receiving tier indefinitely and receives no treatment. Third, if he talks and a report is made and he is committed as a “defective delinquent," he is no longer confined for any portion of the original sentence...If he does not talk, McNeil's sentence continues to run until it expires and yet he is kept at Patuxent indefinitely. ${ }^{48}$

Both Musgrove and McNeil involved inmates seeking release after having been confined at Patuxent well past their criminal sentences. Yet this tactical use of law against the institution also presented more ambiguous opportunities for asserting one’s agency, often framed by the contingencies of disciplinary counter-strategies. After all, as de Certeau points, out:

[a tactic] must play on and with a terrain imposed on it and organized by a foreign power...[i]t operates in isolated actions, blow by blow. It takes advantage of opportunities and depends on them, being without any base where it could stockpile winnings, build up its position, and plan raids. What it wins it cannot keep. ${ }^{49}$

The tactics of peaceful noncompliance sometimes involved using law to fight one incarnation of power only to surrender one's self to another domain of control. Shortly after the court ordered McNeil released, fifty Patuxent prisoners petitioned the circuit court for Montgomery County for writs of habeas corpus and sought transfer to the jurisdiction of the Department of Corrections. ${ }^{50}$ The petitioners, like McNeil, had all agreed to refuse psychiatric evaluation and examination. They contended that since the institution had failed to examine them within the six-month window stipulated by statute, they were entitled to begin serving their criminal sentences. Although the Circuit Court once again concurred and ordered the prisoners transferred, the order was reversed on appeal.

The Court of Appeals cited its opinion in Musgrove and a series of other cases where the language in Article 31 B, §7 (a) had been interpreted as directive and not mandatory if suspects failed to cooperate with the examination process. This effectively meant that the expiration of a prisoner's criminal sentence would be the only limit on Patuxent's confinement of undiagnosed prisoners (a 
precedent set by McNeil’s case). At the same time, new disciplinary strategies were introduced in the institution's procedures to close the window of opportunity engendered by inmate resistance. The Cash ruling expanded the institution's capacity to diagnose uncooperative "suspects" by allowing a finding of defective delinquency based solely on the "historical data in the file of each individual". ${ }^{51}$ As a result of this policy 34 of the 50 petitioners in the case were diagnosed as defective delinquents without examination.

Yet the above solution also exposed the unresolved and divergent imperatives at the core of Patuxent's unique blend of law and norm. Article 31B's legitimacy rested upon the dual claim that: (1) there existed an objective category of offenders called defective delinquents and (2) that Patuxent's staff, armed with the rigor of the scientific method and years of clinical expertise, could make valid diagnoses of them. In turn, the capacity of staff to make such truth claims, rested upon the integrity of the examination. As we have seen, the examination staged a confrontation between the prisoner's self-representation and his documentary and clinical reconstruction; it provided an opportunity to discover buried pathologies and tendencies as well as generating the very general and specific data (e.g., case-studies) that gave Patuxent staff's claim to expertise legitimacy.

This tension between the divergent imperatives of legal procedure and scientific knowledge were laid bare in the testimony of Dr. Harold Boslow (Patuxent's director) in an appeal to the commitment order of Ronnie Smith (one of the petitioner's in the Cash case that had been diagnosed as defective delinquent) (Smith v. Director, 1975). Boslow was questioned by Smith’s counsel as to the reliability of a guilty diagnosis without a personal interview.

I don’t think its desirable, but it's the only thing we can do... [I]n view of the patient's persistent refusal to see either psychiatrist, psychologist or social worker, and the Court's pressing us to produce a document, we produced a document. I don’t think its desirable, but I think that it's a good opinion and it's the best that we can offer under the circumstances. Smith's lawyer noted that when asked the same question in a previous case, Boslow had stated that a diagnosis without a personal interview was “...non-valid, superficial and unethical and impossible.” A few minutes of verbal sparring ensued until an exasperated Boslow replied: 
Your client refuses to take the examination. You say that's all right. We don’t have anything to offer the Court except our review of his history. Now, my experience with twenty years in this particular situation, and more before that, indicates to me that this man's behavior in the community and his entire life history indicate that he is dangerous. I have nothing else to go on. If you want your client to have a fair shake, advise your client to take the examinations. ${ }^{52}$ Smith lost the appeal and was recommitted to Patuxent despite his lawyer's move for mistrial. Yet Boslow's comments reveal a growing schism in the tenuous arrangement of law and regulatory norms that gave Patuxent coherence.

A few months after Smith v. Director was decided, the Courts of Appeals had before it another two non-cooperatives that had also been petitioners in the Cash case. Unlike Smith, Madison Fulwood and Melvin Williams had been ordered to cooperate with Patuxent's examination process on penalty of being held in contempt of court. After hearings before the Criminal Court of Baltimore to show cause for why they refused to follow the court's order, the two were held in contempt and were transferred to the Department of Corrections until they would agree to examination by the Institution. Their original criminal sentences of five years had expired by the time the case was heard by the Court of Appeals and although the court denied their release and reiterated that they would remain in contempt until they submitted to examination, it was becoming increasingly clear that such a policy could not form an effective strategy to curb noncompliance en masse.

By this time as well, prisoner tactics had secured further legal interventions into the management of the institution. For example, sixteen inmates had filed actions for habeas corpus, injunctive and declaratory relief against Patuxent and successfully forced it to adopt a disciplinary code (which it apparently lacked), limit the amount of time prisoners could be placed in deprivation cells and allow them access to the press (McCray et al. v. Patuxent, 1971; reported in State of Maryland et al. v. McCray et. al. 1972). Outside the institution, Patuxent's critics also became more vocal and prominent: an alliance of civil libertarians and fiscal conservatives (the Maryland Coalition Against Patuxent) attacked the institution’s inordinate cost per capita, its tendency to over-predict dangerousness and the ideological premises of the indeterminate sentence. The group found a willing 
soapbox in the News American, a local paper that sought to boost stagnating sales by publishing sensational and critical stories about Patuxent and the indeterminate sentence. ${ }^{53}$

In 1976, following the repeated submission of bills to close Patuxent in previous sessions, the Maryland House of Delegates voted to repeal the Defective Delinquency statute. The Senate deferred action until an evaluation report on the institution commissioned by the Governor could be considered. The 264-page report, conducted by an independent commission from Massachusetts (the Contract Research Corporation), was devastating. It noted that the clinical model endorsed at Patuxent was "inadequate and inaccurate as a basis for any theory or practice of the treatment of offenders". It further argued that the reliable prediction of potential or future dangerousness was not possible and that Patuxent's history illustrated that such an effort had lead to significant over-prediction. This invalidated the ideological premises of the indeterminate sentence itself: if one could not predict dangerousness, how could one assess when offenders stopped being dangerous? The commission also reviewed the statute's juridical application by considering the extensive court decisions and documents discussed above and interviewing the judges, inmates and staff that took part in them. It concluded that while from a legal standpoint, Article 31B had not violated due process it had been inconsistently and unfairly applied. But perhaps the most damning aspect of the report was its appraisal of the institution's efficacy in curbing recidivism:

It was projected that during the nearly ten-year analysis period offenders who had spent time in Patuxent would have a 69 percent chance of being reincarcerated. This would be compared with the 72 percent chance experienced by offenders sent to the Division of Corrections. In short, there were very modest benefits resulting from the substantially higher costs of Patuxent. ${ }^{54}$

The legislature voted to repeal the defective delinquency statute and the indeterminate sentence (as well as bringing Patuxent under the control of the Department of Corrections) the following year.

The demise of Article 31B and the impact of inmate non-compliance also needs to be understood within the context of national events and wider strategies of prisoner rebellion and 
resistance. Foremost among these was the Attica prison riot in September of 1971, its dramatic unfolding in the full light of media coverage and the ensuing public hearings before a citizens' blueribbon commission that investigated New York State’s heavy-handed response (32 inmates and 10 hostages were killed in the retaking). If Attica and the cumulative successes of prisoner rights suits in New York effectively critiqued and destabilized the functioning of the "hands-off doctrine" and the model of sovereign punishment that it enabled, events unfolding in California prisons had a similar impact on the treatment and medical approach that had been championed as its alternative. ${ }^{55}$ The California Prison system with its adjustment centers and rich menu of behavior modification programs (e.g., biblio-therapy and group counseling) had been one of the staunchest supporters of penal welfarism since the mid-1940s. ${ }^{56}$ Not surprisingly, it also served as incubation chamber for some of the most varied and effective strategies of prisoner resistance. Besides the strikes and riots that punctuated daily life in the state’s prisons throughout the late 1960s and early 1970s, inmate writers like Caryl Chessman, Eldridge Cleaver and George Jackson evocatively captured the inconsistencies, injustices and paradoxes of the rehabilitation model for a national audience:

[I]n treatment eras convicts' stories as literature—convicts’ origins, descent into crime, capture, and reform through imprisonment-must become a source of moral instruction for others outside the prison and a model of penitence. When this is not the case, it is a sign that something has gone seriously wrong in the functioning of the rehabilitative prison. ${ }^{57}$

The rapid collapse of the progressive rehabilitation model that had dominated much of the $20^{\text {th }}$ century cannot be understood without reference to the above events, even as the broad radicalization of prisoner strategies and outlooks that fuelled them served equally well as justification and legitimation for fin de siècle law and order strategies within prisons and without (e.g., the War on Drugs). ${ }^{58}$ If the first victim of these critiques was the indeterminate sentence, roundly critiqued from both left and right for either failing to deliver equity in sentencing or failing to provide rehabilitative outcomes, the second was the notion that prisoners through reform and rehabilitation could be anything more than monsters. ${ }^{59}$ Patuxent itself epitomizes this shift: in 1988, the institution came 
under criticism again but this time because it had released two notorious offenders (a triple murderer and a rapist) on a furlough program very similar to the Massachusetts Furlough Law that had released Willie Horton and had been associated with Michael Dukakis’ failed presidential bid. In the wake of sustained criticism, the director resigned, the Board of Review suspended all leaves and the legislature rewrote numerous portions of the institution's enabling statute through emergency legislation; what treatment character remained was decisively altered. ${ }^{60}$

\section{Juridical Power and Disciplinary Exclusion}

If a crucial flaw in Patuxent's disciplinary regime was the systemic instability generated by prisoner resistance, it also clear that the institution's staff recognized it and sought to curtail it formally as early as 1964. In a report by a gubernatorial commission appointed to recommend changing the methods of selection for Patuxent's population, the Board of the Institution made a strong case for doing away with the indeterminate sentence altogether. In its place they argued, the state should adopt a system of "extended” penal sentences not exceeding thirty years for both Patuxent and the wider penal system.

Although the proposal was framed in terms of allaying prisoner fears at the prospect of a life sentence at Patuxent, its central purpose was to forestall the looming hornet's nest introduced by noncompliance. The fact that non-compliance destabilized the treatment regime's ideological premises was a significant but not insurmountable institutional hurdle. The problem was that it brought to the fore a series of institutional questions that could not be managed within the existent Patuxent context without broader reorganization and rethinking. These questions, which would figure prominently in the Contract Research Corporation's report 12 years later, involved: problems of scale (the capacity of Patuxent institution and its ability to implement its strategies when noncooperation became a mass phenomenon), recidivism (the empirical reliability of the institution's portrayal of successful rehabilitation cases) and cost (Patuxent funding dramatically eclipsed spending for the rest of the 
state's penal wing). Indeed, the commission was convened to address the institution's steady population increases and the fact that it would soon be overcapacity.

What remains striking however is the strategy proposed by the commission: rather than increasing the number of cells or erecting new buildings, the committee argued for the deeper penetration of the Patuxent model into the state penal system. It noted that half of the prisoners that had been identified as defective delinquents had received sentences shorter than five years and that in the majority of cases the typical length was 2-3 years. Under such conditions the possibility of a life sentence itself generated despondent tendencies:

Where offenders have received such relatively short sentences, the subsequent indeterminate sentence, with its possibility of life imprisonment, frequently causes great resentment, inspires efforts to obtain release by court proceedings rather than by parole after successful treatment at Patuxent, and inhibits such treatment. ${ }^{61}$

Under the proposal, Patuxent would treat and accept only those prisoners most amenable to treatment; those who resisted (and were thus incorrigible defective delinquents) would be housed by the Department of Corrections under extended penal sentences. Further, the commission recommended that Patuxent's staff could periodically examine these prisoners to determine whether in the intervening period they had become "receptive”.

Commitment to Patuxent, after incarceration in the penal system, but under an extended term rather than under an indeterminate life sentence, might well promote their willingness to accept the treatment which is an essential of rehabilitation at Patuxent. ${ }^{62}$

The proposal nicely illustrates the reliance of disciplinary authority on legal framing and the widereaching instability generated by non-compliance. It also discloses an important point about how the logic of colonization functions. It is not that abnormality cannot be wholly managed or controlled internally: from a normative standpoint new rationales and technologies are always possible. Yet abnormality also presents a disciplinary system with new shores to colonize, new opportunities for expansion and externalization. This is, after-all, how disciplinary logics unfold and reproduce 
themselves. In this sense, inmate resistance helped expose the vulnerabilities pregnant in disciplinary logic itself.

In Patuxent's case, mass abnormality furthered a categorical shift in how the institution could be understood, framed and interrogated; it hastened a reckoning between the institution's normative imperatives and the established legal protections and guarantees of criminal law. In this sense resistance to discipline through law remains a viable prospect but requires the coterminous, tactical engagement of power in both domains. Yet the document also highlights the point that such strategies gain traction in the context of how disciplinary systems reproduce and expand themselves. If the legislature had acted on the proposal, the inassimilable non-cooperatives would have provided the justification and rationale for Patuxent's further penetration of penal space. Indeed the system of “extended sentences” recommended would have given Patuxent a broader remit and wider reach—in part transforming state correctional facilities into auxiliary components of its treatment approach.

Finally, the Patuxent cases provide significant insight into the role of law under the 'sign' of discipline. The legal and normative zone set up by Article 31B is a curious counterpart to the "handsoff doctrine” that typified $19^{\text {th }}$ and early $20^{\text {th }}$ century legal approaches to incarceration. In most respects it styled itself as a direct challenge and refutation of the kind of sovereign model of punishment that reduced its charges to bare-life. ${ }^{63}$ Rather than a zone for law's withdrawal, it is a sphere of tremendous legal activity in which Judges are continually tinkering with, policing, and expanding the reach of the disciplinary apparatus. Many of these key decisions are also notable in that they are occurring against the backdrop of an active Supreme Court that is systematically interrogating the traditional, discretionary prerogatives of state agents particularly in the area of criminal justice (e.g., Mapp v. Ohio, 1961; Miranda v Arizona, 1966, even Furman v. Georgia, 1972).

Clearly, the Maryland courts were students of law; they read opinions and kept abreast of developments. Indeed it is precisely this vigilant, scholarly and careful approach that generated such a barrage of patient initiated litigation. Yet, ironically, the only way to construct a pure disciplinary institution, beholden only to itself and entirely guided by expert opinion was to position it behind a formidable array of legal barricades. And in this sense, as much as Patuxent was the quintessential 
disciplinary experiment, it was above all a legal project constructed, shaped and defended by law. This begs the question: what sort of law is this?

In Patuxent's case law appears to shed its state and sovereign mantle and acts in service of expert knowledge and clinical experimentation. At the same time, it appears to be a form of law that cannot help being what it is. Despite the fact that its fundamental aim seems to be to unseat itself, to render its prerogative to judge moot, it still cannot help being a conduit for at least some kind of resistance and justice. Indeed it is this conduit despite itself, despite its evident intent and its clear orientation to competing norms. This is true in the area of resistance as it is in the arena of exclusion. Though it consciously sought to move beyond the logic of sovereignty and dispossession, the legal thicket of exclusionary policies erected in the name of science is comparable and in many respects much more durable and palpable.

\section{Cases Cited:}

Blizzard v. State (1958), 218 Md. 384.

Dickerson v. Director (1964), 235 Md. 668.

Director, Patuxent Institution v. Clifton Cash et al. and Gerald Booker v. State of Maryland ex rel. Board of Patuxent Institution.(1972), 269 Md. 331.

Director v. Daniels, (1966), 243 Md. 16.

Eggleston v. State, (1956), 209 Md. 504.

Furman v. Georgia, (1972), 408 U.S. 238.

Kennedy v. Martinez, (1963) 372 U.S. 144.

Mapp v. Ohio, (1961) 367 U.S. 643.

McNeil v. Director, (1972) 407 U.S. 245.

Miranda v Arizona, (1966) 384 U.S. 436.

State v. Musgrove (1966) $241 \mathrm{Md} .521$.

Palmer v. State, (1957) 215 Md. 142.

Purks v. Director, (1961) 224 Md. 643.

Purks v. State, (1961) 226 Md. 43.

Sas v. State of Maryland, (1969) 295 F. Supp. 389.

State v. McCray, (1972) 267 Md. 111. 
Tippett v. State, (1971) 436 F.2d 1153.

Smith v. Director, (1975) 27 Md. App. 618.

State of Maryland et al. v. McCray et. al,. (1972) 267 Md. 111.

\footnotetext{
${ }^{1}$ See: “Convict Joins Own Blood Stream To That of Girl Dying of Cancer,” New York Times, June 4, 1949; “Blood Exchanger Named,” New York Times, June 23, 1949; “Sing Sing Lifer Freed by
} Dewey_Traded Blood With Dying Child,” New York Times, December 23, 1949; “Convict’s Blood Gift Fails to Save Girl, 8,” New York Times, June 15, 1949; “Freed Ex-Convict Aids Leukemia Study,” New York Times, June 2, 1951.

${ }^{2}$ Ludwik Gross, M.D. “Leukemic Blood Transfusion,” Letters to the Times, New York Times, June 8, 1949.

${ }^{3}$ See: “Sheppard Volunteers: Prisoner is Being Used in Cancer Experiment,” New York Times, March 28, 1958 and "Sheppard Found Well,” New York Times, June 28, 1961. Also: "Malaria Remedy Tested in Prison,” New York Times, July 23, 1944; “New Drugs to Combat Malaria Are Tested in Prisons for Army,” New York Times, March 5, 1945; “Convicts Aiding Science,” New York Times, July 21, 1953; “Women Prisoners and Jaundice Test,” New York Times, September 4, 1950;

“Prisoners Help Test Drug for Malaria,” New York Times, Mar 16, 1966; “Prisoners Play Vital Role In Scientific Experiments,” New York Times, May 11, 1952.

${ }^{4}$ See generally: Allen M. Hornblum, Acres of Skin: Human Experiments at Holmesburg Prison (New York, Routledge, 1998); Jessica Mitford, The American Prison Business (Harmondsworth, Penguin, 1977) for links between prisoner experimentation and institutions like Patuxent.

${ }^{5}$ Jonathan Simon, Poor Discipline: Parole and the Social Control of the Underclass (Chicago, University of Chicago Press, 1993); Richard Singer “Consent of the Unfree: Medical Experimentation 
and Behavior Modification in the Closed Institution. Part I” Law and Human Behavior, 1 (1977), 1-

43; Roy G. Spece, jr., “Conditioning and Other Technologies Used to "Treat?" "Rehabilitate?"

"Demolish?" Prisoners and Mental Patients” Southern California Law Review, v. 45 (1972), 616-684.

${ }^{6}$ For example, between 1935 and 1939, five states had passed “sex psychopath” laws and between 1947 and 1955, 21 additional states (and the District of Columbia) passed similar laws. Ohio’s legislature set aside upwards of one million dollars for a specialized facility at Lima State Hospital in 1949 and California transferred men sentenced as sexual psychopaths from mental hospitals across the state to a purpose-built institution for their treatment at Atascadero State Hospital in 1954. Estelle B. Friedman, “'Uncontrolled Desires’: Responses to the Sexual Psychopath, 1920-1960”, Journal of American History 74 (1987), 96-100.

${ }^{7}$ See: Francois Ewald, “Norms, Discipline, and the Law,” Representations 30 (1990): 138-61; Alan Hunt. "Foucault’s Expulsion of Law: Toward a Retrieval,” Law and Social Inquiry 17 (1992): 1-30; Alan Hunt and Gary Wickham, Foucault and Law: Toward a Sociology of Law as Governance (London, Pluto, 1994); Nikolas Rose and Mariana Valverde, “Governed by Law?” Social and Legal Studies 7(1998): 569-79; Nikolas Rose, Pat O’Malley, Mariana Valverde, “Governmentality.” Annual Review of Law and Social Science 2 (2006): 83-104; Ben Golder and Peter Fitzpatrick Foucault’s Law (London, Glasshouse/Routledge, 2009); Mariana Valverde, “Specters of Foucault in Law and Society Scholarship” Annual Review of Law and Social Science 6 (2010), 45-59.

${ }^{8}$ See for example: Caleb Smith, "Detention without Subjects: Prisons and the Poetics of Living Death,” Texas Studies in Literature and Language, 50 (2008) and Caleb Smith, The Prison and the American Imagination (New Haven: Yale University Press, 2009); Colin Dayan, The Law is a White Dog: How Legal Rituals Make and Unmake Persons (Princeton and Oxford: Princeton University Press, 2011).

9 “Report of Commission to Study and Re-Evaluate Patuxent Institution”, Legislative Council of the General Assembly of Maryland, January 25, 1961, 9.

${ }^{10}$ Manfred Guttmacher and Henri Weihofen, Psychiatry and the Law (New York, Norton, 1952), 444. ${ }^{11}$ Op.Cit., 445. 
${ }^{12}$ Op. Cit., 446.

${ }^{13}$ The full list of crime categories gives a sense of the broadness of the act's scope: felonies, misdemeanors punishable by imprisonment in the penitentiary; crimes of violence; three types of sexcrimes (involving either an age disparity, physical force or of an uncontrolled or repetitive nature) or two or more convictions for offenses punishable with imprisonment. Md. Ann. Code art. 31B, 1951.

${ }^{14}$ McNeil v. Director (1972) at 257.

${ }^{15}$ Purks v. State, at 48.

${ }^{16}$ See: Dickerson v. Director (1964) and Sas v. Maryland (1969)

${ }^{17}$ These included: a) whether the sanction involved an affirmative disability or restraint; b) whether it historically had been regarded as punishment; c) whether it came into effect solely based on a scientific finding; d) whether its purpose was to promote the traditional aims of punishment (deterrence and retribution); e) whether the behavior to which it applied was already a crime; f) whether an alternative purpose to which it could be rationally connected could be assigned to it; and g) whether it appeared excessive in relation to the alternative purpose assigned (see, Kennedy $v$. Martinez, 1963).

${ }^{18}$ According to the plaintiffs, the constitutional violations included: a) the evidentiary status of Patuxent reports, b) the state's burden of proof, c) whether the Patuxent's indeterminate sentence constituted double jeopardy, d) the inability to contest an order for examination by Patuxent, e) the possibility of self-incrimination during examination.

${ }^{19}$ Tippett v. State at 1159.

${ }^{20}$ The outcome of Patuxent commitment hearings could (and frequently were) appealed and, once an inmate had reached 2/3 of his original criminal sentence (or two years whichever was longer), he could file for a redetermination of the defective delinquency finding (and thereafter at 3 year intervals). Additionally, throughout the 1950s the Maryland courts experienced a dramatic increase in habeas corpus petitions from state prisoners (495 between 1957-1958 alone) which generated a substantial number of appeals (when these were denied) and published opinions (when they reached the Court of Appeals). The legislature enacted the Post Conviction Procedure Act in 1958, which 
allowed a prisoner to challenge a state criminal conviction collaterally. It was designed to reduce court caseloads (particularly with respect to the writ) because it limited prisoners to a single postconviction petition in a trial court (which should include all remedies and reliefs sought) and one opportunity to seek leave to appeal. However, wary that restricting access to habeas corpus would invalidate constitutional protections, the legislature and courts continued to allow habeas corpus actions, thereby ensuring that it remained a separate remedy. Edward Tomlinson, "Post-Conviction in Maryland: Past Present, Future” Maryland Law Review 45 (1986), 934-936.

${ }^{21}$ Michel Foucault, Society Must be Defended, eds. Mauro Bertani and Alessandro Fontana (New York, Picador, 2003), 38-39.

${ }^{22}$ On the distinction between Juridico-discursive power and the legal complex see: Rose and Valverde, “Governed by Law?”; Golder and Fitzpatrick, Foucault’s Law; Ewald, “Norms, Discipline, and the Law".

${ }^{23}$ Michel Foucault, The History of Sexuality, Volume I, (New York, Vintage, 1990), 144.

${ }^{24}$ Op. Cit., 86-87.

${ }^{25}$ Michel Foucault, Security, Territory, Population, ed. Michel Senellart (New York, Picador, 2007), 119; History, 89.

${ }^{26}$ Foucault, History, 89.

${ }^{27}$ Foucault, Society, 39.

${ }^{28}$ Rose and Valverde, “Governed by Law?”, 543; Ewald, “Norms, Discipline, and the Law,”138.

${ }^{29}$ Austin Sarat, “...The Law is All Over”: Power, Resistance and the Legal Consciousness of the Welfare Poor” Yale Journal of Law \& the Humanities 2(1990), 346.

${ }^{30}$ Op. Cit., 347.

${ }^{31}$ Michel Foucault, Psychiatric Power, ed. Jacques Lagrange (New York, Palgrave, 2006), 43.

${ }^{32}$ See for example: Michel Foucault, Discipline and Punish (New York, Vintage Books, 1977), 55-

57. This circular, self-referential aspect of sovereignty is reflected in one of the enduring preoccupations of legal theory: the premises of law's own internal validity. See for example, Hans 
Kelsen’s Pure Theory of Law or H.L.A. Hart's Concept of Law or John Austin's The Philosophy of Positive Law.

${ }^{33}$ Foucault, Psychiatric Power, 42-45 and Security, 57.

${ }^{34}$ Michel Foucault, Abnormal, eds. Valerio Marchetti and Antonella Salomoni (New York, Picador, 2003), 50 .

${ }^{35}$ Foucault, Psychiatric Power, 53-55. See also: Georges Canguilhem, The Normal and the Pathological, (Cambridge and London, MIT Press, 1991), 243.

${ }^{36}$ Foucault, Psychiatric Power, 54.

${ }^{37}$ Department of Public Safety and Correctional Services, Maryland's Defective Delinquency Statute—A Progress Report, (State of Maryland, January 9, 1973), 17.

${ }^{38}$ See: David B. Wexler, “Token and Taboo: Behavior Modification, Token Economies, and the Law” California Law Review 61 (1973) and “Of Rights and Reinforcers,” San Diego Law Review 11 (1973). ${ }^{39}$ Mitford, American Prison Business, 113-115; Dept. of Correctional Services, Maryland's Defective Delinquency Statute, 18.

${ }^{40}$ Phil Stanford, “A Model, Clockwork-Orange Prison,” The New York Times, September 17, 1972; E. Barrett Prettyman, Jr. “The Indeterminate Sentence and the Right to Treatment” American Criminal Law Review 11 (1972), 21-23. Indeed it is significant that when the legislature decided to end the 25year "defective delinquent" experiment in July of 1977 and decided redefine the purpose of the institution to handle exclusively “dangerous offenders”, it made remarkably few architectural security changes. Elice H. Zenoff and Thomas F. Courtless, “Autopsy of an Experiment: the Patuxent Experience,” Journal of Psychiatry and the Law, (5) 1977.

${ }^{41}$ See: Stanford, “A Model, Clockwork-Orange Prison”; Mitford, American Prison Business and American Correctional Association, A Study of Maryland State Department of Correction (Washington, ACA, 1966), 223, 231. As well as: Hayes v. Secretary of the Department of Public Safety (1972). 
${ }^{42}$ A point well illustrated by the fact that of the 155 inmates Patuxent released in ten years (19551965), only $17 \%$ were actually released by the IRB; the remaining 129 prisoners were released as a result of Court intervention, Director v. Daniels, 1965.

${ }^{43}$ According to Mitford, 10 psychiatrists, 11 psychologists, 17 social workers, 9 educational personnel, 11 vocational training personnel, 4 recreational personnel, 12 medical personnel, 6 classification personnel and 9 dietary staff (Mitford, American Prison Business, 113).

${ }^{44}$ Foucault, Discipline and Punish, 181-182.

${ }^{45}$ Article 31 B, §7 (a) stated that Patuxent’s staff would “...state their findings in a written report addressed to the court, not later than six months from the date said person was received in the Institution for examination, or three months, before expiration of his sentence, whichever first occurs." See: Director, Patuxent Institution v. Clifton Cash et al. (1972) and Gerald Booker v. State of Maryland ex rel. Board of Patuxent Institution.

${ }^{46}$ Regardless of "what the law says [cooperating with staff] would be incriminating yourself, because you would run the risk of staying in jail the rest of your life” (Musgrove v. State, 1966).

${ }^{47}$ Under Maryland law if he had served his sentence in state prison he would have been eligible for parole after 15 months.

${ }^{48}$ McNeil v. Director (1972) at 257.

${ }^{49}$ Throughout this essay I have been using de Certeau’s depiction of the tactic as “ ....an art of the weak"; "a calculated action that is determined by the absence of a proper locus”. Michel de Certeau, The Practice of Everyday Life (Berkley and Los Angeles, University of California Press, 1984), 37. ${ }^{50}$ See: Director, Patuxent Institution v. Cash et al.; Booker v. State of Maryland ex rel. Board of Patuxent Institution (1972).

${ }^{51}$ These included FBI reports (a number of Patuxent prisoners during this period were Black Muslims active in the movement), pre-sentencing reports, prior psychological and psychiatric histories, police files, information from previous adult and juvenile sentences, hospital records, employment and school information, military service records, etc.

${ }^{52}$ Smith v. Director, 1975 at 632. 
${ }^{53}$ See for example: P. Browning Hoffman, "Patuxent, Psychiatry and Politics: The Psychological Pursuit of Policy or The Perils of Pauline in Policy-Land” Journal of the American Academy of Psychiatry and the Law 7(1), 1979 and "Patuxent Institution from a Psychiatric Perspective, Circa 1977,” Journal of the American Academy of Psychiatry and the Law 5(2), 1977. Thomas F. Courtless, “The Rehabilitative Ideal meets an Aroused Public: the Patuxent Experiment Revisited” The Journal of Psychiatry and Law, 17 (1989). Also: Robert A. Gordon, “Preventative Sentencing and the Dangerous Offender,” British Journal of Criminology, 22(3), 1982, 292-293. Contract Research Corporation, Evaluation of Patuxent Institution-Final Report (Maryland, Maryland Department of Public Safety and Corrections, 1977).

${ }^{54}$ Hal B. Shear, “An Overview of the Contract Research Corporation Evaluation of Patuxent Institution” Journal of the American Academy of Psychiatry and the Law 5(2), 1977, 141-142. According to Courtless (see note 53) Patuxent was relatively free of external scrutiny until a 1971 paper by Emory F. Hodges. Hodges argued that without Article 31B, 1,500 additional crimes would have been committed by released prisoners if they had been sent to regular prisons rather than Patuxent Institution (see Emory F. Hodges, “Crime Prevention by the Indeterminate Sentence,” American Journal of Psychology 128(3) 1971). Thus, given the fact that incarceration at Patuxent per inmate was twice the cost of incarceration in Department of Corrections, the institution's impact on recidivism was central to the discussion.

${ }^{55}$ On the impact of prisoner rights suits in New York State (particularly the impact of the Black Muslim cases) see: Sarah Barringer Gordon, The Spirit of the Law: Religious Voices and the Constitution in Modern America, (Cambridge and London, Harvard University Press, 2010) pp. 115131. On sovereign punishment in New York State: Luca Follis, “Resisting the Camp: Civil Death and the Practice of Sovereignty in New York State,” Law, Culture and the Humanities 9(1), 2013. On the Attica riot and its aftermath: Bert Useem and Peter Kimball, States of Siege: US Prison Riots 19711986 (New York: Oxford University Press, 1991), Chapter 3. 
${ }^{56}$ On Penal Welfarism see: David Garland, The Culture of Control (Oxford: Oxford University Press, 2001). For a history of California’s treatment approach and its radicalization: Eric Cummins, The Rise and Fall of California's Radical Prison Movement (Stanford, Stanford University Press, 1994).

${ }^{57}$ Cummins, Rise and Fall, 265. See also: Donald F. Tibbs, From Black Power to Prison Power: The Making of Jones v. North Carolina Prisoners' Labor Union (New York, Palgrave MacMillan, 2012). ${ }^{58}$ See for example: Francis Allen, The Borderland of Criminal Justice (Chicago, U of Chicago Press, 1964), Noval Morris, The Future of Imprisonment (Chicago U of Chicago Press, 1974) James Q.

Wilson, Thinking about Crime (New York, Vintage Books, 1975).

${ }^{59}$ Kathleen Daly and Michael Tonry, “Gender, Race and Sentencing,” Crime and Justice 22 (1997).

${ }^{60}$ Courtless, “The Rehabilitative Ideal meets an Aroused Public”, 615-617.

${ }^{61}$ State of Maryland, Interim Report of Commission to Study Changes and Basis of Selection for Patuxent Institution (Annapolis, State of Maryland, 1964), 15.

${ }^{62}$ Op.Cit., 13.

${ }^{63}$ Giorgio Agamben, Homo Sacer: Sovereign Power and Bare Life (Stanford: Stanford University Press, 1998). 